13 Proceedings of the Second Annual Forestry Symposium 1996: Management and Sustainable Utilization of Forest Resources, Sri Lanka, 6-7 December 1996. (Eds. Amarasekera, HS, Ranasinghe, D M S HK and Finlayson, $W$. Published by Department of Forestry and Environmental Science, University of Sri Jayewardenepura, Sri Lanka(1998)

\title{
TRAINED AND COMPETENT PERSONNEL - A PREREQUISITE FOR SUSTAINABLE FOREST MANAGEMENT
}

\author{
D.J. Danbury \\ Sri Lanka Forestry Institutc (ODA) \\ Not:: The views expressed in this paper are those of the author, and do not necessarily \\ reflect the official policy of the UK Overseas Development Administration
}

\begin{abstract}
4 general discussion of the requirements for training at professional, technician, and operative levels in the Sri Lankan context. There should be no rigid barriers to the promotion of outstanding individuals from one level to another. There is a particular need for short courses to cater for continuing education and training. The establishment of a national training council is recommended.
\end{abstract}

\section{Introduction}

The theme of this symposium is particularly appropriate at a time when Sri Lanka is about to embark on the first five-year implementation phase of the Forestry Sector Master Plan (FSMP, 1995). The plan for the conservation and sustainable development of forest resources is designed to meet wide ranging economic, social and environmental objectives. It proposes a steadily increasing level of activity over the next 25 years.

The successful implementation of the FSMP proposals will require a body of well trained and competent persomnel, across both state and private sectors. It is important that people at all levels - professional, technical, and operative - are actively involved in this development. There will need to be adequate provision of education and training, by both full-time and short in-service routes. There must be a constant awareness of the need to develop the persomel, already in the forestry sector, in whatever capacity, and of the need for future recruitment and training to take only of individuals of the highest calibre.

\section{The professional forester}

With two universities offering degrees in forestry or forestry-related subjects Sri Lanka is now producing a more than adequate number of graduates for the forestry sector. The recently updated curriculum for the MSc course at the University of Sri Jayewardenepura (USJP), and the inclusion of forestry as one-third of a BSc general degree, will further help to produce graduates well fitted for their future roles. However, a first or even a higher degree must be regarded as only the starting point of a career as a professional forester. 
The two essential attributes of young professionals are scholarship and capability: scholarship to know how to seek out knowledge and develop new methods, and capability to apply these in practice. They should constantly ask, and seek satisfactory answers to the "why" questions. These attributes can be developed in a number of ways. Learning on the job under the professional mentorship of a senior colleague, if such a person is available, is a time honoured process and can be very valuable. However, this way of learning must be complemented by a constant awareness of the individual's own responsibilities to the profession.

The concept of continuing professional development (CPD) is embodied in many professions. Why should keeping abreast of developments be regarded as less vital in forestry than in other disciplines? The UK Institute of Chartered Foresters requires that its members undertake a minimum of 100 hours of CPD in any three-year period (ICF, 1991). This encompasses attendance on courses, seminars, meetings and study tours, presentation of papers, and keeping up to date with the literature. Formalizing this process in the UK has taken many years and the forestry profession there is many times larger than that in Sri Lanka. It is not suggested that formal CPD could readily be introduced here. However, even with a professional forester cadre of fewer than 200 persons there is a strong case for the formation of some type of foresters' association or institute. It would set standards for the profession, and assist in the process of developing cohesiveness and public credibility, just as has been the case with the Institution of Engineers of Sri Lanka, founded 90 years ago (Munasinghe, 1996).

Meanwhile it is up to each individual to be aware of his or her needs for new information, and seek out ways to meet them. Attendance at this symposium is a very good example of professional development activity. Sri Lanka is also lucky that a considerable number of workshops sponsored by international agencies take place either in the country or in the region. Although these opportunities exist, however, there is no satisfactory alternative to having an awareness of the literature through self study, of both local and international material.

Armed with this information, the forester will be able to develop the capability to be a competent forest manager, recognizing needs and implementing either established or new technology whenever appropriate. Much bad practice in forestry and wood use is due to the failure to apply existing knowledge. For example, why are most plantations in Sri Lanka still established with unselected stock, when provenance and tree improvement research has been going for more than 60 years? Why is so much timber marketed with inadequate grading, seasoning, and preservation?

In most countries young people enter forestry because of an interest in biology and the environment. An indication that this observation applies to Sri Lanka is that, from a list of 78 student forestry research projects conducted at USJP from 1983 to 1993 (Ranasinghe \& Amarasekara, 1994), only four were in the subject of forest management. Foresters must be encouraged to further their professional development in the core subjects relating to sustainable management. As forestry is a broadly based profession there should be no 
difficulty in encompassing the newer social objectives, though it is well to remember, as Roche (1992) pointed out, that all good forestry produces social benefits.

Nonetheless, in the implementation of the Master Plan across the whole forestry sector, there will be situations where a forestry training will not be appropriate for the task in hand. It will be the forester's responsibility to recognise such situations, and to call in and work with professionals in other disciplines.

It is admitted that CDP is never easy. Most foresters have a hectic daily schedule of administration and other immediate problems. A good starting point is the recognition of one's responsibility not only to one's employer, but to one's own training needs and wider contribution to the forestry profession.

\section{The forestry technician}

Forestry technicians, the middle-level officers, are in many ways the key to successful forest management. They form the essential link between the relatively few professional foresters and the many manual workers who carry out the field tasks. Technicians both provide information up the line to aid decision making and are responsible for implementing the programme determined

The two essential attributes of the forestry technician are knowledge and competence: knowledge of current practice, and competence to apply it to the highest standards and with the minimum of supervision.

At the Sri Lanka Forestry Institute (SLFI) there are well developed programmes for training senior technicians (Range Forest Officers) by the two-year diploma, and junior tehnicians (Bcat Forest Officers) by the one-ycar certificate courses. In each case the curriculum is as relevant as possible to current and future perceived needs (HUKS, 1991) and is subject to continuous reinterpretation and regular revision. The acquisition of knowledge, while it is a necessary foundation, must be built upon by practical application. At least a third and in some subjects up to half of the total time on SLFI courses is occupied by practical instruction and practice. in the classroom, laboratory, workshop or field.

Practical competence testing as a regular part of instruction gives trainees confidence in their ability to carry out field and office duties to the right specification, using the correct method and to the right degree of accuracy. The good technician must be able not only to answer the "low" but also the "how many" or "how much" questions.

To take an example from forest inventory, the technician must be trained to measure the height of a tree, not just to be able to describe the process in a written examination, but to do it in the field consistently and to a defined level of accuracy, say to the nearest metre. It cannot be stressed too highly that this is a vital part of technician teaching, and that trainces should only be deemed to have passed when they have achieved satisfactory standards in all the elements of a practical task. In this example, if a field officer consistently over or underestimates tree heights, data which will subsequently be included in FORDATA (Pallot, 1996) 
will be incorrect. A database in which confidence can be placed is essential both for the informed formulation of forest policy and for the development of management plans.

In addition to such technical competence, the forest technician needs to have a thorough training in supervisory and interpersonal skills, particularly if working in one of the larger organisations. The ability to motivate the workforce in the field is crucial to the successful implementation of annual plans of operations.

As with the professional forester, there is an equal need for technical staff to keep up-lo-date with new ideas and methods. In this respect it is not realistic to expect any but the top cadre of technicians to have the capacity or opportunity for self-study. Away from the larger offices, there is less contact with experienced senior foresters. and what published material is available will usually be in the English language, presenting additional problems for many junior officers

Employing organizations, through their senior staff, have to be aware of the continuing training needs of field staff and to seek ways of meeting these needs. Short in-service training courses are already quite well developed in Sri Lanka, being offered by a number of institutions. But as forestry technical staff are increasingly called upon to take part in the work of cncouraging of private sector partners. new techniques will have to be learned.

In the conduct of extension and participatory programmes, field staff will need to have the confidence and enthusiasm that are needed to put across new concepts, while respecting the indigenous knowledge of nural people. They must also be competent in the demonstration of practical skills, and be able to advise small producers and contractors in setting up enterprises. For participation in more general awareness progranmes, whether aimed, for example, at schools or at the general public, staff should develop good communication skills. including the use of appropriate visual aids.

Although these newer skills are often best developed by practice, the basic training at SLFI already includes the preparation and delivery of extension matcrial, and real-life field exercises in rural appraisal. There has been no difficulty in trainees accommodating the attitudinal reorientation necessary for these roles and there is a general welcome for the wider duties that will become part of the forestry technician's work in future.

\section{Operatives and partners}

As the implementation of the FSMP progresses, a more diverse body of personnel will be involved in carrying out practical forestry operations on both state and private land. They will range from direct-labour employees, through self-employed contractors, to community groups and owner occupiers. They may be specialists requiring only one or two skills, or they may have to turn their hands to many different operations as general craftsmen.

The many practical tasks include nursery work, planting, silvicultural operations, protection, harvesting, transport, sawmilling and wood processing. For each task the question that has to be asked is "what is the best way to do it?". 
There is a vast array of traditional agricultural skills available in Sri Lanka, but it should not be assumed that this also applies to forestry skills, many of which will be less familiar to the nural people; training can usually improve technique. Benefits accrue in two areas: productivity, and health and safety. The benefits are not only for the individual, but also for the organization and ultimately the nation.

Much training at the operator level is best done on the job by demonstration and practice. Where more formal centre-based craft training is undertaken it should be targeted at key personnel, who can then pass on their newly acquired skills to others - "training the trainers".

As labour costs rise and production increases there will be pressure to further mechanize some forest operations, particularly harvesting. The correct teaching of mechanical skills will be necessary to ensure efficient and safe practice. Indeed certain codes of practice may well become mandatory as labour and safety legislation develop. For example, many countries have legislation which prohibits the use of chainsaws by untrained or under-age personnel, and requires specified items of safety clothing to be worn. In Sri Lanka one sees horrifying cxamples of the incorrect use and maintenance of chainsaws. The sub-optimal efficiency of such bad practice, together with the social costs of injury, clearly point to the need to address the situation if forest industries are to develop as planned. Training must play a vital part.

\section{Incentives}

At cvery level of education and training there has to be the correct incentive to motivate the trainee to learn. It is often said that forestry is a vocation and one should feel privileged to be part of it. However it is generally unrealistic to expect this sort of altruism - cxcept from those with alternative sources of income! Intellectual challenge and job satisfaction can be motivating factors, but ultimately incentives must be related directly or indirectly to financial reward.

For the organization, better training of personnel results in more effective achievement of management objectives. All personnel will know clearly the job they have to do, and will be able to carry it out with minimum supervision to an acceptable output and level of accuracy. Training is a good investment, but the returns must accrue to both the organization and the individual.

For professionals and technicians in either the state or private sectors, career progression is probably the prime motivation. In the public sector there are clear structures and procedures for promotion, though they have the disadvantage of inflexibility. With the moves in Sri Lanka toward enterprise-orientated state organizations, the use of private-sector type incentives, such as performance-related awards, may become possible. Already it is encouraging to note that the Forest Department recognizes the higher grades of certificates and diplomas awarded at SLFI by an additional incremental scale point. 
For professionals the opportunity to attend postgraduate courses, overseas training courses and study tours acts as a strong incentive, but it is important that selection criteria are scrupulous in ensuring the selection of the most deserving candidates.

Fewer such opportunities arise for technical staff, but it is important that the best technicians have the opportunity to progress to professional posts. The Forest Department has an excellent record in this respect in that there is provision for promotion of outstanding Foresters to the ACF grade. In future, with the increasing recnitment of graduates, this route may not be so open. There is little incentive for an SLFI diplomate to embark on an ab-initio degree course. Few would have the money or the time. The possibility deserves consideration that in some subjects credits might be granted by the universities for high-level diplomas. It would be unlikely, however, that the number of such candidates would ever justify the development of a separate "end-on" degree course.

For operatives the incentives to train are directly related to their daily lives. Trained employees will carry out their tasks more effectively and with more regard to their health and safely. For direct employees, however, training will only be an attractive proposition if there is "a fair day's pay for a fair day's work". The benefits to the organization must be passed on to the trained staff. Often this transference is best achieved by adopting the practices of piecework or bonus payments.

Self-employed contractors and owner occupiers will benefit from training by achieving greater output and reducing lost time. However, people in these categories will have to be convinced of the value of training if they are to take time off, with possible loss of income, to attend training courses.

\section{Training needs and structure}

The FSMP programme on human resources calls for a detailed identification of education and training needs, the strengthening of education and training institutions, and for humanresources development systems to be put in place.

The FSMP's personnel requirement projections, assuming full implementation. indicate little change in the state institutions, but a doubling of those employed in the non-state sector. The training needs of this potentially new and varied workforce will need to more accurately assessed. This assessment will involve a pro-active manpower planning approach, and also an in-depth survey of current needs. Once the numbers and requirements of potential trainees have been determined, the right education and training provision can be planned with confidence.

Education and training in the forestry sector are provided at present by a number of institutions: the universities, government departments (including SLFI), international and bilateral aid agencies, and NGOs. As FSMP implementation proceeds it will be necessary for new training programmes to develop, particularly to meet private sector needs. This development will generally be within the technical capacity of the existing institutions, but they will need to work out new modes of delivery and funding. State sector institutions will 
need greater freedom to charge and retain fee income, and their clients will have to be prepared to pay for training at an economic rate.

There will be a need for greater coordination of education and training. Although institutions are aware of each other's existence, they are not always sufficiently aware of each other's programmes. The FSMP proposes the establishment by USJP of an education and training network in forestry, to coordinate professional and technical training. This network would be a useful start, but what is really required is a coordinating body for all levels of training across the entire forestry sector.

A national forestry training council should be established with wide representation of all interested parties. The council should be at a sufficiently senior level for its recommendations to be acted upon. It should have a small secretariat in the appropriate ministry, and a technical committee to plan and initiate the necessary activity.

Provision of information would be a priority function of such a committee. What is the target population, what are their needs, who can do the training, and how will it be funded? The preparation of a directory of training opportunities and courses would be a useful first step. Gaps in provision could then be identified and organizations invited to fill them.

With this structure in place the forestry institutions would be well placed to initiate their own human resources development programmes with confidence. They would be able to develop and retain a cadre of trained and competent personnel, the prerequisite for the management and sustainable utilization of forest resources.

\section{References}

FSMP (1995). Sri Lanka Forestry Sector Master Plan. Ministry of Agriculture, Lands and Forestry.

HUKS (1991). Technical Report No.5. Sri Lanka Forestry Institute, Helsinki University Knowledge Services.

ICF (1991). Continuing professional development guidelines: Edinburgh, Institute of Chartered Foresters.

Munasinghe, M. (1996). Sustainable development: the role of engineers. Daily News, Colombo, 1 Nov.

Pallot, J. (1996). The application of computer database technology to forest plantation management in Sri Lanka. Second Annual Forestry Symposium, 1996, University of Sri Jayewardenapura.

Ranasinghe, E.D.M.S.H.K. and Amarasekera, H.S. (1994). Forestry research projects 19831993 - a summary. Forestry Unit, University of Sri Jayewardenapura.

Roche, L. (1992). The profession of forestry now and in the year 2000. Commonwealth Forestry Review 71 (1). 